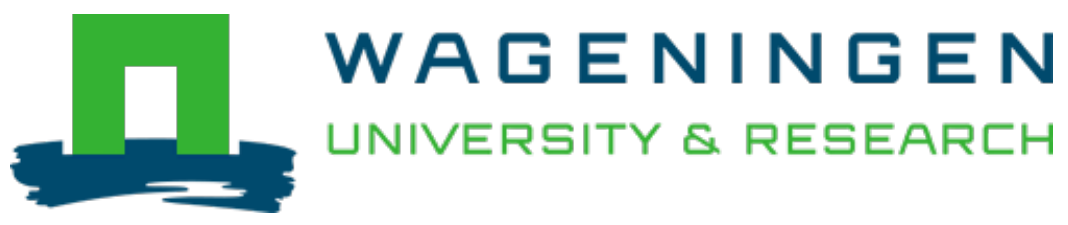

\author{
Dormancy, activation and viability of Rhizopus oligosporus sporangiospores \\ International Journal of Food Microbiology \\ Thanh, N.V.; Nout, M.J.R. \\ https://doi.org/10.1016/j.ijfoodmicro.2003.09.008
}

This publication is made publicly available in the institutional repository of Wageningen University and Research, under the terms of article $25 \mathrm{fa}$ of the Dutch Copyright Act, also known as the Amendment Taverne. This has been done with explicit consent by the author.

Article $25 \mathrm{fa}$ states that the author of a short scientific work funded either wholly or partially by Dutch public funds is entitled to make that work publicly available for no consideration following a reasonable period of time after the work was first published, provided that clear reference is made to the source of the first publication of the work.

This publication is distributed under The Association of Universities in the Netherlands (VSNU) 'Article $25 \mathrm{fa}$ implementation' project. In this project research outputs of researchers employed by Dutch Universities that comply with the legal requirements of Article $25 \mathrm{fa}$ of the Dutch Copyright Act are distributed online and free of cost or other barriers in institutional repositories. Research outputs are distributed six months after their first online publication in the original published version and with proper attribution to the source of the original publication.

You are permitted to download and use the publication for personal purposes. All rights remain with the author(s) and / or copyright owner(s) of this work. Any use of the publication or parts of it other than authorised under article $25 \mathrm{fa}$ of the Dutch Copyright act is prohibited. Wageningen University \& Research and the author(s) of this publication shall not be held responsible or liable for any damages resulting from your (re)use of this publication.

For questions regarding the public availability of this publication please contact openscience.library@wur.nl 


\title{
Dormancy, activation and viability of Rhizopus oligosporus sporangiospores
}

\author{
N.V. Thanh ${ }^{\mathrm{a}}$, M.J.R. Nout ${ }^{\mathrm{b}, *}$ \\ ${ }^{a}$ Biotechnology Research and Development Institute, Can Tho University, Can Tho, Viet Nam \\ ${ }^{\mathrm{b}}$ Department of Agrotechnology and Food Sciences, Laboratory of Food Microbiology, Wageningen University, \\ P.O. Box 8129, Wageningen, EV 6700, The Netherlands
}

Received 22 April 2003; received in revised form 29 July 2003; accepted 17 September 2003

\begin{abstract}
Interruption of dormancy to improve viability of Rhizopus oligosporus sporangiospores is crucial for the application of stored starter cultures for fungal (tempe) production. We aimed to assess the extent of dormancy and factors that could result in activation. Whereas heat treatments were unsuccessful, Malt Extract Broth (MEB) showed to be a good activation medium, with $80 \%$ of dormant spores being activated as measured by fluorescence microscopy using a fluorescent marker, compared with $11 \%$ with the control. Peptone and yeast extract but not glucose played an important role in activating dormant spores. Metabolically active (fluorescent) and swollen spores, followed by germ tubes were obtained after activation in MEB for 25 min., 2 and $4 \mathrm{~h}$, respectively, at $37{ }^{\circ} \mathrm{C}$. Simultaneously, some interesting transitions took place. Dormant spores represent $85-$ $90 \%$ of the total spores at harvest and after drying. Their number decreased to $21-32 \%$ after activation with MEB with a concomitant increase of metabolically active spores. As a result of storage, some dormancy was lost, yielding an increase of active spores from $11.2 \%$ at harvest to $28.8 \%$ after 3 months storage. Levels of active spores were well correlated with their viability. By activation of dormant spores, their viability increased; levels of viable and active spores were maximum in 1 month old starter $(61.7 \%$ and $75.9 \%$ of total spores, respectively) but gradually decreased with concomitant increase of the number of dead spores.
\end{abstract}

(C) 2003 Elsevier B.V. All rights reserved.

Keywords: Inoculum; Dormancy; Viability; Rhizopus; Spores; Activation; Fluorescent markers

\section{Introduction}

The development of fungal spores can be arbitrarily distinguished into several stages: formation, maturation, dormancy, after-ripening, activation and germination (Griffin, 1994). Dormancy is a common

\footnotetext{
* Corresponding author. Tel.: +31-317-482834; fax: +31-317484978.

E-mail address: rob.nout@wur.nl (M.J.R. Nout).
}

strategy to survive unfavourable external conditions. To become germinable after dormancy, many (fungal) spores require an after-ripening period (e.g., a cold period) and/or activation treatment. The latter may include thermal, chemical (detergents, organic acids, and amino acids, etc.), or light activation (Sussman and Halvorson, 1966; Griffin, 1994).

For example, Phycomyces blakesleeanus spores do not germinate in a suitable culture medium unless they are activated by one of a range of treatments, such as 
heating for $3 \mathrm{~min}$ at $44{ }^{\circ} \mathrm{C}$ (Halbsguth and Rudolph, 1959; Van Laere et al., 1980), $\gamma$ radiation (Van Assche et al., 1977), dithionite treatment (Van Assche et al., 1978), or treatments with acetate, azide and ammonia (Van Laere et al., 1980). Likewise, $n$-alcohols and high pressure supported the heat activation of $P$. blakesleeanus (Thevelein et al., 1979) and of Neurospora tetrasperma ascospores (Belmans et al., 1983). During activation, glycerol formation was observed in P. blakesleeanus spores (Van Schaftingen and Van Laere, 1985). Heat treatment was related to trehalase activity in dormant and activated spores of P. blakesleeanus (Van Assche et al., 1972; Van Assche and Carlier, 1975).

Glucose was involved in the initiation of germination of Mucor racemosus sporangiospores (Tripp and Paznokas, 1982a). Furthermore, glucose induced trehalase activity and trehalose mobilization during early germination of $P$. blakesleeanus spores (Thevelein et al., 1983). The availability of glucose also affected events during germination of Syncephalastrum racemosum sporangiospores (Hobot and Gull, 1977).

Whereas amino acids and endogenous protein stimulated germination of $M$. racemosus sporangiospores (Tripp and Paznokas, 1981, 1982b), no single amino acid was as effective as glucose or peptone at triggering germination. So it was suggested that glucose may trigger germination by signalling the breakdown of endogenous protein reserves, while the subsequent increase of free amino acids may be the dormancy-breaking factor.

Earlier studies on the germination of Rhizopus oligosporus sporangiospores (Medwid and Grant,
1984) revealed that two phases: I (swelling) and II (germ tube protrusion), could be distinguished. Initial swelling during phase I occurred only in the presence of a suitable carbohydrate, while subsequent production of germ tubes during phase II required exogenous sources of both carbon and nitrogen. It was also shown (Breeuwer et al., 1997) that germination of $R$. oligosporus sporangiospores is prevented by nonanoic acid, a fungal self-inhibitor. Despite this knowledge, there is a lack of understanding relating to the dormancy and activation of the tempe-mould $R$. oligosporus. In this paper, we present physical and nutritional conditions affecting the activation and germination and the accompanying morphological changes of $R$. oligosporus. We demonstrate shifts in physiological categories (i.e., dormant, metabolically active, viable and dead) of $R$. oligosporus sporangiospores in during storage.

Like in other fungal spores, dormancy occurs in sporangiospores of $R$. oligosporus, especially during storage time; dormancy may well be one of reasons for the limited shelf-life of tempe starter cultures as were reported by several authors, e.g. 4 months at $25-$ $30{ }^{\circ} \mathrm{C}$ (Tanuwidjaja and Roestamsjah, 1985), or 2.5 months (Tunçel et al., 1989). In powdered tempe starters we can distinguish three categories by fluorescence microscopy, namely: metabolically active (green fluorescence with carboxyfluoresceindiacetate), dead (red fluorescence with propidium iodide) and dormant (no fluorescence). In rice-based spore powders, typically more than $90 \%$ of spores were dormant and $5-6 \%$ are metabolically active (Thanh and Nout, 2002). Many, but not all, metabolically

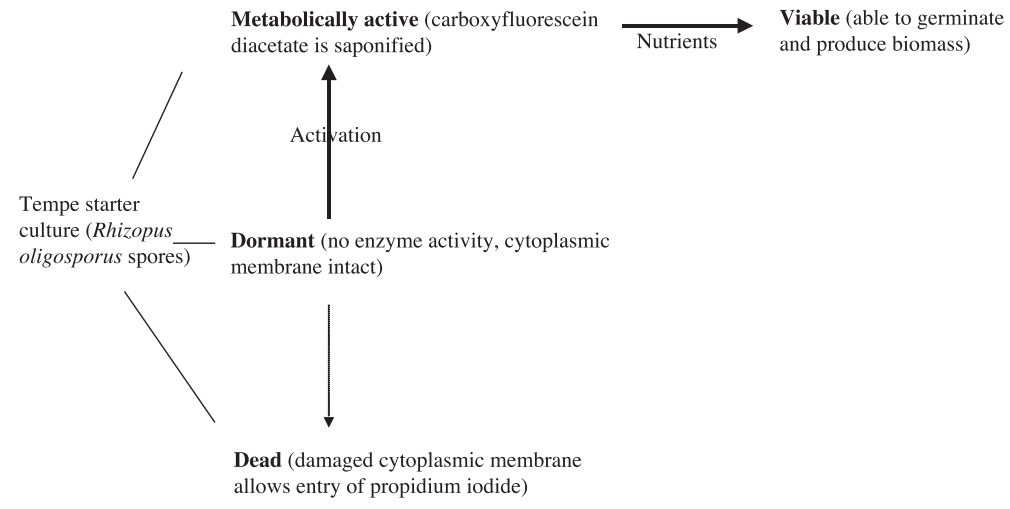

Fig. 1. Physiological categories of R. oligosporus sporangiospores. 
active spores are viable, i.e. able to germinate and produce colonies of biomass. To facilitate the discussion, the relation between these categories is illustrated in Fig. 1.

\section{Materials and methods}

\subsection{Fluorescent probes and media: $c F D A$}

5-(and-6)-carboxyfluorescein diacetate (Molecular Probes Europe, Leiden, The Netherlands), $10 \mathrm{mg} / \mathrm{ml}$ acetone, (cFDA $0.22 \mathrm{mM}$ ) was used as a fluorescent marker for metabolically active spores (see also Sections 2.3 and 2.5 below). PI: Propidium iodide $95-$ 98\% (TLC) (Sigma, St. Louis, USA) 1- $\mathrm{mg} / \mathrm{ml}$ distilled water, $(30 \mu \mathrm{M})$ was used as a fluorescent marker for dead spores (see also Sections 2.3 and 2.5 below). RBCC: Rose-Bengal chloramphenicol Agar Base, Oxoid, CM 549 with addition of $0.2 \mathrm{~g} / 1$ Rose Bengal (Fluka, Switzerland) was used for viability tests (see Section 2.6). MEA: Malt extract agar (malt extract 30 $\mathrm{g} / \mathrm{l}$, mycological peptone $5 \mathrm{~g} / \mathrm{l}$, agar $15 \mathrm{~g} / \mathrm{l}$ ), Oxoid, CM 59 was used in the preparation of tempe starter (Section 2.2) and for viability tests (Section 2.6). MEB: malt extract broth (malt extract $17 \mathrm{~g} / \mathrm{l}$, mycological peptone $3 \mathrm{~g} / \mathrm{l}$ ), Oxoid, CM 57 was used for activation of spores (Section 2.3). CDM: Czapek-Dox liquid medium Oxoid, CM 95 containing sodium nitrate $2 \mathrm{~g} / \mathrm{l}$, potassium chloride $0.5 \mathrm{~g} / \mathrm{l}$, magnesium glycerophosphate $0.5 \mathrm{~g} / 1$, ferrous sulphate $0.01 \mathrm{~g} / \mathrm{l}$, potassium sulphate $0.35 \mathrm{~g} / 1$ and sucrose $30 \mathrm{~g} / 1$ was used for activation of spores (Section 2.3). PPS: Peptone physiological salt solution containing neutralised bacteriological peptone $1 \mathrm{~g} / 1$ (Oxoid, L34) and $\mathrm{NaCl} 8.5 \mathrm{~g} / 1$ was used as a diluant for viability tests (Section 2.6).

\subsection{Preparation of tempe starter}

Tempe starter was prepared as described earlier (Thanh and Nout, 2002). Briefly, the procedure was as follows: $R$. oligosporus LU 575 (NRRL 5905) was grown on MEA plates during 1 week at $30{ }^{\circ} \mathrm{C}$, and spores were harvested by washing with sterile water. The spore suspension was diluted to approximately $10^{5}$ spores per $\mathrm{ml}$. This suspension " $\mathrm{A}$ " was used as inoculum for substrate used to prepare tempe starter.
Polished broken rice was steam-sterilized, allowed to cool and sterilized ammonium sulfate and sterilized $\mathrm{H}_{2} \mathrm{SO}_{4}$ were added to adjust the $\mathrm{pH}$ to 4 , this is the optimal $\mathrm{pH}$ for spore germination of $R$. oligosporus (Medwid and Grant, 1984; Breeuwer et al., 1997). The sterile broken rice $(50 \mathrm{~g})$ was inoculated and thoroughly mixed with $0.4 \mathrm{ml}$ of spore suspension "A". The inoculated rice was incubated at $40{ }^{\circ} \mathrm{C}$ for 2 $\mathrm{h}$, followed by incubation for 4 days at $30{ }^{\circ} \mathrm{C}$. The mouldy mass was broken up and the entire mass of substrate, mycelium and spores was dried at $42{ }^{\circ} \mathrm{C}$ for $48 \mathrm{~h}$ in a forced-air drying cabinet. Only crushing by sterile pestle and mortar, but no fine grinding was used in order to avoid misjudging between spores and rice particles with similar size and shape. The starter powder was stored in screw-cap glass tubes, protected from light, in a silicagel desiccator at $25^{\circ} \mathrm{C}$, as these conditions were considered to be more representative of practical usage than storage at low temperature. Moreover it was shown that spores survive better at ambient $\left(25-30{ }^{\circ} \mathrm{C}\right)$ temperature than at $5{ }^{\circ} \mathrm{C}$ (Thanh and Nout, 2002). The samples were analyzed in triplicate after a defined period of storage.

\subsection{Activation of dormant spores}

Sporangiospores in crushed rice powder were diluted with sterile water to suspensions (approximately $10^{6}$ spores $/ \mathrm{ml}$ ), and were washed twice by centrifugation at $13,000 \times \mathrm{g}$ for $3 \mathrm{~min}$ in an Eppendorf centrifuge. After decanting, the spores in pellets were re-suspended in phosphate buffer $\left(\mathrm{K}_{2} \mathrm{HPO}_{4} 50 \mathrm{mM}\right.$, adjusted to $\mathrm{pH} 4.0$ with citric acid $50 \mathrm{mM}$ ), $\mathrm{CDM}$, and $\mathrm{MEB}$, respectively. Subsequently, the suspensions were either plated on RBCC and MEA to quantify viable spores (see Section 2.6), metabolically active or dead spores (see Section 2.5). At each sampling time point during the activation process, spore suspensions were stained as described in Section 2.5.

\subsection{Total number of spores}

One gram of crushed rice-based spore starter was placed in $99 \mathrm{ml}$ of sterile distilled water containing $0.1 \%(\mathrm{v} / \mathrm{v})$ Tween 80 . The suspension of spores was carried out by vigorous agitation and filtration with a Millipore membrane filter [(fluorassure); Chem filter 15, REF: 100-C2003-01; Chemunex]. Spore suspen- 
sions were diluted as appropriate and counted using a Bürker-Türk counting chamber. Microscopic counts were also made similarly to determine fluorescent spores, as described in Section 2.5.

\subsection{Fluorescent counts of metabolically active and dead spores}

Spore suspensions were washed twice by centrifugation at $13,000 \times g$ for $3 \mathrm{~min}$ in an Eppendorf centrifuge in phosphate buffer $\left(\mathrm{K}_{2} \mathrm{HPO}_{4} 50 \mathrm{mM}\right.$, adjusted to $\mathrm{pH} 4.0$ with citric acid $50 \mathrm{mM}$ ). Subsequently, the suspensions were incubated for $20 \mathrm{~min}$ in the presence of cFDA and PI at $40{ }^{\circ} \mathrm{C}$. They were then put on ice and counted in a Bürker-Türk counting chamber by fluorescence microscopy, with an Axioskop epifluorescence microscope equipped with a 50$\mathrm{W}$ mercury arc lamp, a fluorescein isothiocyanate filter set (excitation wavelength $450-490 \mathrm{~nm}$; emission wavelength $>520 \mathrm{~nm}$ ), an $\times 1001.3$ numericalaperture Plan-Neofluar objective lens, and a camera (Carl Zeiss, Oberkochen, Germany). Fluorescent, non-fluorescent and spores showing germ tubes were counted. Their values were presented in decade log units and percent of total spores. Fluorescent spores (cFDA) were considered as metabolically active, or dead in case of PI fluorescence; non-fluorescent spores were considered as dormant; spores with germ tubes were considered as germinated spores when the extension of the germ tube was to a length equal to one-half the diameter of the spores (Medwid and Grant, 1984).

\subsection{Viability of spores}

Viable spores were determined as colony forming units by surface-plating triplicate $0.1-\mathrm{ml}$ aliquots of decimal dilution series in PPS, on RBCC and MEA. After incubation at $37{ }^{\circ} \mathrm{C}$ for $12 \mathrm{~h}$ (MEA) or 24 h (RBCC), colonies were counted.

\subsection{Statistical analysis}

Experiments were in duplicate, analyses in triplicate. The results were reported as means of triplicates with standard deviation using unrelated $t$ test to test significance of differences.

\section{Results and discussion}

\subsection{Effect of heat and nutrients on activation}

In Table 1, the effects of incubating 2-month old rice-grown as well as fresh MEA-grown spores of $R$. oligosporus, in MEB and buffer are shown. MEB has a significant activation effect as shown by higher numbers of metabolically active (cFDA fluorescent) spores. Attempts to activate spores by heat treatments at at 50 and $60{ }^{\circ} \mathrm{C}$ were unsuccessful. This is in

Table 1

Effect of heat treatments on metabolic activation of fresh and stored spores of $R$. oligosporus

\begin{tabular}{|c|c|c|c|c|}
\hline \multirow[t]{2}{*}{ Activation treatment } & \multicolumn{2}{|c|}{$\begin{array}{l}\text { Metabolically active }{ }^{1} \text { spores of } R \text {. oligosporus } \\
\text { grown on rice and stored for } 2 \text { months at } 25{ }^{\circ} \mathrm{C}\end{array}$} & \multicolumn{2}{|c|}{$\begin{array}{l}\text { Metabolically active spores of } R \text {. oligosporus } \\
\text { grown on MEA for } 4 \text { days, at } 37{ }^{\circ} \mathrm{C}\end{array}$} \\
\hline & $\begin{array}{l}\log N / g \text { dry wt } \\
\text { rice powder } \\
\text { Avg. } \pm \text { S.D. }\end{array}$ & $\begin{array}{l}\% \text { of total } \\
\text { number of } \\
\text { spores }^{2}\end{array}$ & $\begin{array}{l}\log N / \mathrm{ml} \\
\text { suspension } \\
\text { Avg. } \pm \text { S.D. }\end{array}$ & $\begin{array}{l}\% \text { of total } \\
\text { number of } \\
\text { spores }^{2}\end{array}$ \\
\hline $\operatorname{MEB}^{3}\left(37^{\circ} \mathrm{C}, 4 \mathrm{~h}\right)$ & $8.57^{\mathrm{a}} \pm 0.01$ & 79.4 & $8.68^{\mathrm{a}} \pm 0.01$ & 93.3 \\
\hline Buffer $^{4}\left(37^{\circ} \mathrm{C}, 4 \mathrm{~h}\right)$ (Control) & $7.7^{\mathrm{b}} \pm 0.04$ & 10.7 & $8.5^{\mathrm{b}} \pm 0.04$ & 61.7 \\
\hline $\operatorname{Buffer}^{4}\left(50{ }^{\circ} \mathrm{C}, 10 \mathrm{~min}\right)$ & $7.48^{\mathrm{c}} \pm 0.08$ & 6.5 & & \\
\hline $\operatorname{Buffer}^{4}\left(60{ }^{\circ} \mathrm{C}, 3 \mathrm{~min}\right)$ & $7.46^{\mathrm{c}} \pm 0.04$ & 6.2 & $8.46^{\mathrm{b}} \pm 0.23$ & 56.2 \\
\hline Buffer $\left.{ }^{4} 60^{\circ} \mathrm{C}, 10 \mathrm{~min}\right)$ & $7.37^{\mathrm{c}} \pm 0.06$ & 5.0 & & \\
\hline
\end{tabular}

Data reported as means of triplicates with standard deviation. In each column, data with the same indicators are not significantly different ( $p \leq 5 \%$, one-tail unrelated $t$-test).

\footnotetext{
${ }^{1}$ Fluorescent with cFDA

${ }^{2} \log$ total spores $=8.71$.

${ }^{3}$ Malt Extract Broth, Oxoid CM 57.

${ }^{4}$ Buffer was prepared by $\mathrm{K}_{2} \mathrm{HPO}_{4} \cdot 50 \mathrm{mM}$ adjusted to $\mathrm{pH} 4.0$ with citric acid $50 \mathrm{mM}$.
} 
contrast with the very successful activation of $P$. blakesleeanus spores after such heat treatment (Halbsguth and Rudolph, 1959). We conclude that heat activation is not suitable for activation of dormant sporangiospores of $R$. oligosporus.

Table 2 presents data on the effects of control buffer, CDM (Czapek-Dox liquid medium), and MEB (Malt Extract Broth). Incubation in CDM did not result in appreciable activation (low number of fluorescent metabolically active spores). This suggests that its main components, sodium nitrate and sucrose, play no role as activating compounds. The number of fluorescent, i.e. active spores increased strongly by incubation in MEB at $37{ }^{\circ} \mathrm{C}$. In an earlier study (Breeuwer et al., 1997) it was observed that the majority of freshly harvested spores had become fluorescent after $3 \mathrm{~h}$ incubation at $37{ }^{\circ} \mathrm{C}$ in MEB. Our data in Table 2 show that activation with MEB proceeds very quickly. We found that MEB is suitable for activation of dormant spores, even after prolonged storage of 2 months. This suggests that problems relating to limited shelf-life reported earlier (Tanuwidjaja and Roestamsjah, 1985; Tunçel et al., 1989), might have been caused by dormancy and could have been overcome by activation under appropriate conditions. The results of the control in Table 1 show that the number of active spores in fresh MEA-grown spores $(61.7 \%)$ was much higher than that of rice-

Table 2

Effect of incubation time in activation solutions on the metabolic activation of rice-grown spores of $R$. oligosporus stored for 2 months at $25{ }^{\circ} \mathrm{C}$

\begin{tabular}{|c|c|c|c|c|c|c|}
\hline \multirow{2}{*}{$\begin{array}{l}\text { Incubation } \\
\text { time }\end{array}$} & \multicolumn{2}{|c|}{ Buffer $^{1}$ (control) } & \multicolumn{2}{|l|}{$\mathrm{CDM}^{2}$} & \multicolumn{2}{|l|}{$\mathrm{MEB}^{3}$} \\
\hline & $\begin{array}{l}\log N / g \\
\text { dry wt }\end{array}$ & $\begin{array}{l}\% \text { of } \\
\text { total }^{5}\end{array}$ & $\begin{array}{l}\log N / g \\
\text { dry } \mathrm{wt}^{4}\end{array}$ & $\begin{array}{l}\% \text { of } \\
\text { total }\end{array}$ & $\begin{array}{l}\log N / g \\
\text { dry } \mathrm{wt}^{4}\end{array}$ & $\begin{array}{l}\% \text { of } \\
\text { total }^{5}\end{array}$ \\
\hline $5 \min ^{6}$ & 7.75 & 12.0 & 7.48 & 6.5 & 8.52 & 70.8 \\
\hline $2 h^{6}$ & 7.72 & 11.2 & 7.65 & 9.6 & 8.54 & 74.1 \\
\hline $4 h^{6}$ & 7.51 & 6.9 & 7.74 & 11.8 & 8.58 & 81.3 \\
\hline $6 \mathrm{~h}^{6}$ & 7.53 & 7.2 & 7.84 & 14.8 & 8.57 & 79.4 \\
\hline $8 h^{6}$ & 7.47 & 6.3 & 7.80 & 13.5 & 8.55 & 75.9 \\
\hline
\end{tabular}

${ }^{1}$ Buffer: $\mathrm{K}_{2} \mathrm{HPO}_{4} .50 \mathrm{mM}$ adjusted to $\mathrm{pH} 4.0$ with citric acid 50 $\mathrm{mM}$.

${ }^{2}$ Czapek-Dox medium, Oxoid CM 95.

${ }^{3}$ Malt Extract Broth, Oxoid CM 57.

${ }^{4} N=$ cFDA fluorescent spores; dry wt: dry weight of sample.

${ }^{5}$ Log total spores $=8.67$.

${ }^{6}$ Measured after $20 \mathrm{~min}$ for fluorescent staining at $40{ }^{\circ} \mathrm{C}$ in buffer ${ }^{1}$. grown spores stored for 2 months (10.7\%) and when activated in MEB, fresh spores can be activated up to $93 \%$. This means that not only stored spores, but also fresh spores benefit from MEB activation.

The mechanistic base for dormancy of $R$. oligosporus is not known. In Aspergillus oryzae, it has been shown (Horikoshi and Iida, 1964) that spore coats contain higher levels of glucosamine and protein; spore walls of Rhizopus stolonifer are multilayered (Hawker and Abbott, 1963) and superficial lipid on the asexual spores of $R$. stolonifer prevents wetting (Fisher et al., 1972). Such physico-chemical conformations of the spore surface could prevent nutrient uptake and activation. Considering the rapid activation of dormant spores of $R$. oligosporus as shown in Table 2, we conclude that its dormancy is not caused by such factors, but rather by deficiency of certain nutrients.

We also tested whether MEB may still be limited in its concentrations of activating component(s), by carrying out the activation experiments of Table 2 with MEB (normal strength) to which D-Glucose $(0.5 \%), \mathrm{NH}_{4} \mathrm{Cl}(0.1 \%)$, and $\mathrm{KH}_{2} \mathrm{PO} 4(0.15 \%)$ were added, and with 1.5-fold concentrated MEB. Similar numbers of fluorescent and germinated spores were found (data not shown) which makes us conclude that the levels in MEB are adequate to activate dormant spores.

\subsection{Activation, germination and viability as affected by exposure to $M E B$}

The activation, swelling and germination sequence followed by mycelial growth of $R$. oligosporus sporangiospores is shown in Table 3. The number of activated spores quickly exceeded nine decade log units ( $42 \%$ of total spores) already after $5 \mathrm{~min}$ of exposure to MEB, whereas the maximum was reached after $6 \mathrm{~h}$ ( $70 \%$ of total spores). Spore swelling, the first visible phase of germination, had started between $20 \mathrm{~min}$ and $2 \mathrm{~h}$. Next, the emergence of germ tubes followed after $4 \mathrm{~h}$, with 8.99 decade $\log$ unit increasing to 9.27 decade $\log$ unit (55\% of total spores) after $6 \mathrm{~h}$. However, after $8 \mathrm{~h}$ the outgrowth of germ tubes caused such entwinement that counting was not reliable anymore. Our results agree with earlier reports (Ekundayo and Carlile, 1964; Medwid and Grant, 1984; Breeuwer et al., 1997) that germination pro- 
Table 3

Activation, germination and viability of rice-grown spores of $R$. oligosporus stored for 3 months at $25{ }^{\circ} \mathrm{C}$ after exposure to Malt Extract Broth at $37{ }^{\circ} \mathrm{C}$

\begin{tabular}{|c|c|c|c|c|c|c|}
\hline \multirow[t]{2}{*}{ Time } & \multicolumn{2}{|c|}{ Active spores ${ }^{\mathrm{a}}$} & \multicolumn{2}{|c|}{ Germinated spores $^{\mathrm{b}}$} & \multicolumn{2}{|c|}{ Viable spores $^{\mathrm{c}}$} \\
\hline & $\begin{array}{l}\log N / g \\
\text { dry } w t^{d}\end{array}$ & $\begin{array}{l}\% \text { of } \\
\text { total }\end{array}$ & $\begin{array}{l}\log N / g \\
\text { dry } w t^{f}\end{array}$ & $\begin{array}{l}\% \text { of } \\
\text { total }^{\mathrm{e}}\end{array}$ & $\begin{array}{l}\log \text { CFU/g } \\
\text { dry wt }\end{array}$ & $\begin{array}{l}\% \text { of } \\
\text { total }^{\mathrm{e}}\end{array}$ \\
\hline $0 \min ^{\mathrm{g}}$ & 0 & 0 & 0 & 0 & & \\
\hline $5 \min ^{\mathrm{g}}$ & 9.15 & 41.7 & 0 & 0 & & \\
\hline $10 \min ^{\mathrm{g}}$ & 9.16 & 42.7 & 0 & 0 & & \\
\hline $15 \min ^{\mathrm{g}}$ & 9.19 & 45.7 & 0 & 0 & & \\
\hline $20 \min ^{\mathrm{g}}$ & 9.21 & 47.9 & 0 & 0 & 8.63 & 12.6 \\
\hline $2 h^{g}$ & 9.25 & 52.5 & $\begin{array}{l}0 \\
\text { (swollen) }\end{array}$ & 0 & 8.96 & 26.9 \\
\hline $4 h^{g}$ & 9.32 & 61.7 & 8.99 & 28.8 & 9.28 & 56.2 \\
\hline $6 \mathrm{~h}^{\mathrm{g}}$ & 9.37 & 69.2 & 9.27 & 55.0 & 9.16 & 42.7 \\
\hline $8 \mathrm{~h}^{\mathrm{g}}$ & $\begin{array}{l}\text { Not } \\
\text { countable }\end{array}$ & & $\begin{array}{l}\text { Not } \\
\text { countable }\end{array}$ & & & \\
\hline
\end{tabular}

${ }^{\text {a }}$ Fluorescent with cFDA.

${ }^{\mathrm{b}}$ Showing germ-tubes.

${ }^{\mathrm{c}}$ Producing colonies on MEA and RBCC.

${ }^{\mathrm{d}} N=$ fluorescent spores.

${ }^{\mathrm{e}}$ Log total spores $=9.53$.

${ }^{\mathrm{f}}$ Dry $w \mathrm{t}=$ dry weight of spore powder.

${ }^{\mathrm{g}}$ Measured after $20 \mathrm{~min}$ for fluorescent staining at $40{ }^{\circ} \mathrm{C}$ in buffer $\left(\mathrm{K}_{2} \mathrm{HPO}_{4} .50 \mathrm{mM}\right.$ adjusted to $\mathrm{pH} 4.0$ with citric acid $\left.50 \mathrm{mM}\right)$.

${ }^{\mathrm{h}}$ Caused by mycelial entwinement.

ceeded through two distinguishable phases, viz. phase 1 the enlargement of the sporangiospores and phase 2 the emergence of a germ tube. Table 3 shows that the number of viable spores increased from $8.63 \log$ units
(12.6\% of total) after 20 min activation, to its highest value of $9.28 \log$ units $(56.2 \%$ of total) after $4 \mathrm{~h}$ and then decreased slightly. We expect this decrease to be an artefact caused by mycelial entwinement and physical damage to germ tubes during surface plating; both will decrease the number of colonies to some extent. After $4 \mathrm{~h}$ we obtained higher levels of viability than visible germ tubes probably because the spores that had swollen started to form germ tubes during plating on MEA medium. This assumption is supported by the increase of germinated spores between 4 and $6 \mathrm{~h}$.

\subsection{Effect of some carbon and nitrogen sources on viability of stored (11 months) spores}

As shown above, MEB containing peptone and maltose, is a good activation medium. The effect of complex carbon and nitrogen sources on germination and colony formation (viability) of dormant spores is shown in Table 4 for (1) MEB as a control, (2) glucose $2 \%$, (3) peptone $1 \%$, (4) yeast extract $1 \%$, (5) casamino acids $1 \%$, and (6) combined glucose and peptone. Without incubation or after an incubation during $4 \mathrm{~h}$ at $37{ }^{\circ} \mathrm{C}$ of the dormant spores, the activated spores were spread-plated on the same solutions to which $1 \% \mathrm{w} / \mathrm{v}$ Agar Bacteriological (Oxoid L11) had been added. Colonies were counted after $12 \mathrm{~h}$. The data show the effects of activation

Table 4

Effect of some carbon and nitrogen sources on viability of rice-grown spores of $R$. oligosporus stored for 11 months at $25^{\circ} \mathrm{C}$

\begin{tabular}{|c|c|c|c|c|}
\hline \multirow[t]{2}{*}{ Activation solution } & \multicolumn{2}{|l|}{ Without activation } & \multicolumn{2}{|l|}{ Activation ${ }^{1}$ at $37^{\circ} \mathrm{C}, 4 \mathrm{~h}$} \\
\hline & $\log$ CFU/g Avg. \pm S.D. & $\%$ of total ${ }^{2}$ & $\log$ CFU/g Avg. \pm S.D. & $\%$ of total ${ }^{2}$ \\
\hline 1. $\mathrm{MEB}^{3}$ & $8.53^{\mathrm{a}} \pm 0.03$ & 36.3 & $8.63^{\mathrm{a}} \pm 0.05$ & 45.7 \\
\hline 2. Glucose G $^{4}(2 \%)$ & $<7.0^{\mathrm{c}}$ & $<1.1$ & $<7.0^{\mathrm{c}}$ & $<1.1$ \\
\hline 3. Peptone ${ }^{5}(1 \%)$ & $8.51^{\mathrm{a}} \pm 0.04$ & 34.7 & $8.63^{\mathrm{a}} \pm 0.04$ & 45.7 \\
\hline 4. Yeast extract ${ }^{6}(1 \%)$ & $8.52^{\mathrm{a}} \pm 0.06$ & 35.5 & $8.59^{\mathrm{a}} \pm 0.05$ & 41.7 \\
\hline 5. Casamino $\operatorname{acids}^{7}(1 \%)$ & $7.96^{\mathrm{b}} \pm 0.05$ & 12.0 & $8.25^{\mathrm{b}} \pm 0.06$ & 19.1 \\
\hline 6. Glucose ${ }^{4}(2 \%)+$ peptone $^{5}(1 \%)$ & $8.49^{\mathrm{a}} \pm 0.04$ & 33.1 & $8.59^{\mathrm{a}} \pm 0.04$ & 41.7 \\
\hline
\end{tabular}

Data reported as means of triplicates with standard deviation. In each column, data having the same indicators are not significantly different ( $p \leq 5 \%$, one-tail unrelated $t$-test).

${ }^{1}$ Spores were incubated in activation solution.

${ }^{2} \log$ total spores $=8.97$.

${ }^{3}$ MEB: Malt Extract Broth, Oxoid CM 57.

${ }_{\mathrm{D}}^{4}(+)$-Glucose-Monohydrate, Merck, Art. 1.08342.

${ }^{5}$ Peptone aus Casein, Merck, Art. 7213.

${ }^{6}$ Yeast Extract, Oxoid L21.

${ }^{7}$ Bacto vitamin-free casamino acids, Difco, Art. 0288-01. 
(incubation in activation solution) and of individual components. On glucose alone, viability was very low. Activation in casamino acids increased viability from $12.0 \%$ to $19.1 \%$ but the viability was significantly lower than in MEB, peptone, yeast extract and glucose + peptone which were not significantly different. It was reported (Ekundayo and Carlile, 1964) that the initiation of germination of $R$. arrhizus sporangiospores required the presence of glucose or fructose and that germinating spores were transferred to a medium lacking glucose, swelling soon ceased. Glucose was also essential for initiation of spore swelling and germ tube emergence in S. racemosum (Hobot and Gull, 1977); both quickly ceased when glucosegrown cultures shifted down to non-permissive glucose-free medium. Our data also show that only glucose is insufficient to allow colony formation. Obviously, additional nitrogen and mineral sources will be required for germination and colony formation. In early studies on the slime mold Dictyostelium discoideum (Cotter and Raper, 1966) it was noted that the spores were constitutively dormant and did not release myxamoeba if merely suspended in buffer; however, each spore released a simple myxamoeba if peptone were added to the buffer. When the component parts of peptones were tested (exclusive of peptides), the amino acids were mainly responsible for germination whereas vitamins, salts and glucose had no effect. Our data suggest a similar response by $R$. oligosporus. It was interesting to note that even after 11 months of storage, the viability of spores activated by MEB was still rather high $(45.7 \%$ of total). This is partly due to the fact that the moulded rice was not finely milled since we observed that fine grinding gives considerable losses of viability (Thanh and Nout, 2002).

\subsection{Dormancy, activation and viability of spores during a production and storage trial}

We studied metabolic activity and viability from production up to 16 months storage of rice-based spore concentrate by measuring total number of spores, metabolically active spores, dormant spores, viable spores, and dead spores. Fig. 2 shows that at harvest most spores $(85.1 \%)$ are in the dormant stage, and only $11.2 \%$ are active. Of the dormant spores, more than $60 \%$ could be activated. Activation treatment did not increase the viability of freshly harvested spores; we assume that they were too sensitive to the staining temperature $\left(40{ }^{\circ} \mathrm{C}\right)$ or they were too young. After mild drying, a general but

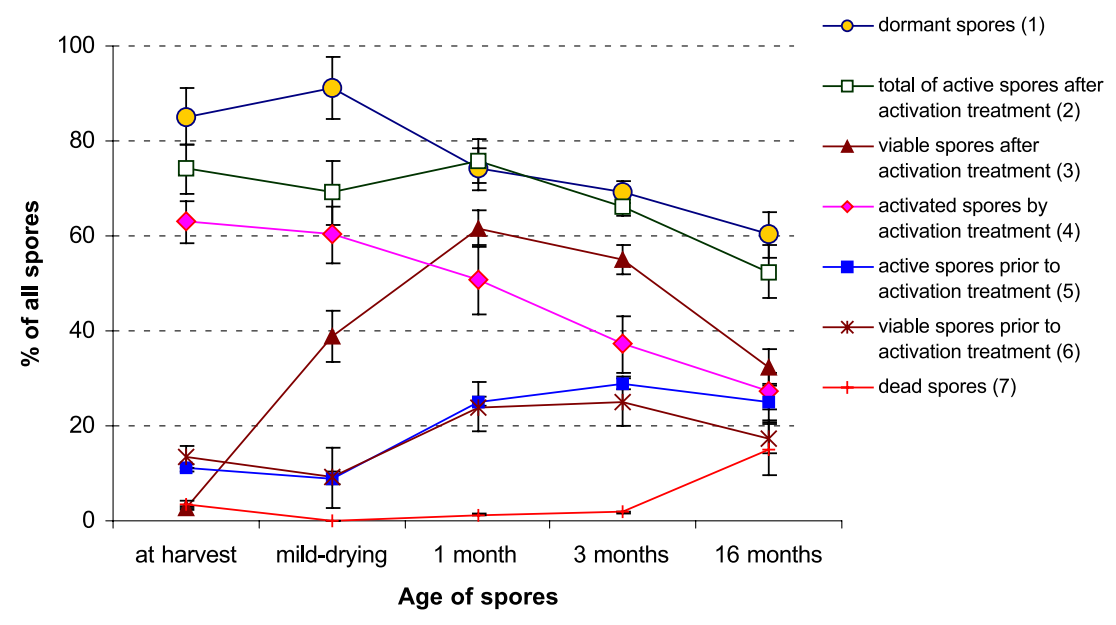

Fig. 2. Activity, dormancy, and viability of $R$. oligosporus sporangiospores in a rice-based spore concentrate: (1) spores lacking enzyme activity, but with intact cytoplasmic membrane; (2) sum of active spores prior to activation treatment and activated spores; (3) sum of viable spores prior to activation treatment and increased viability by activation treatment; (4) spores activated from dormancy by activation treatment; (5) metabolically active spores without activation treatment; (6) viability without activation treatment; (7) spores with damaged cytoplasmic membrane allowing entry of propidium iodide. 
slight decrease of active and viable spores was observed. As noticed earlier (Thanh and Nout, 2002) this must be caused by the drying temperature of $42{ }^{\circ} \mathrm{C}$ and the loss of moisture which renders rehydration more difficult. We found however, that the viability of dried spores could be enhanced considerably by activation.

After 1 month storage and thereafter, no dead germ tubes were observed anymore, indicating that the spores were maturing, stabilizing their structure and possibly recovering from the drying treatment. After 1-month storage, viability after activation was highest at $8.74 \log$ units $(61.7 \%$ of total), and decreased gradually during further storage to $32.4 \%$ after 16 months. This is in conformity with earlier data (Rusmin and Ko, 1974; Wang et al., 1975) showing that the germination percentage of processed spores decreased rapidly during the early storage period. After 3 months of storage, the number of active spores had increased to $8.41 \log$ unit (28.8\%), with concomitant decrease of dormant spores. This would suggest that during storage, some dormant spores woke up, i.e. changed to active spores. After 16 months of storage, a considerable number of stored spores had died (8.13 log units, or $15.1 \%$ of total), and the number of viable spores had strongly decreased to $8.2 \log$ unit $(17.38 \%)$, whereas activation was not very effective any longer. The data after 16 months indicate that dormant spores could still be activated but that active spores could hardly germinate anymore.

In conclusion, we found that the majority of sporangiospores of $R$. oligosporus in rice-based starter are in a dormant stage. During storage, some of the dormant spores become active. The numbers of active and viable spores correlate well. Most dormant spores can be activated by MEB, peptone or yeast extract, with concomitant increase of viable spores.

\section{Acknowledgements}

This work was supported in part by IFS grant no. C/3399-1. N.V. Thanh gratefully acknowledges receipt of the sandwich fellowship from the Netherlands organization for international cooperation in higher education (NUFFIC). We wish to thank Dr. Pieter Breeuwer for help with fluorescence techniques.

\section{References}

Belmans, D.L., Van Laere, A.J., Van Assche, J.A., 1983. Effect of $\mathrm{n}$-alcohols and high pressure on the heat activation of Neurospora tetrasperma ascospores. Archives of Microbiology 134, 49-51.

Breeuwer, P., De Reu, J.C., Drocourt, J.-L., Rombouts, F.M., Abee, T., 1997. Nonanoic acid, a fungal self-inhibitor, prevents germination of Rhizopus oligosporus sporangiospores by dissipation of the $\mathrm{pH}$ gradient. Applied and Environmental Microbiology $63,178-185$.

Cotter, D.A., Raper, K.B., 1966. Spore germination in Dictyostelium discoideum. Proceedings of the National Academy of Science U. S. 56, 880-887.

Ekundayo, J.A., Carlile, M.J., 1964. The germination of sporangiospores of Rhizopus arrhizus: spore swelling and germ-tube emergence. Journal of General Microbiology 35, 261-269.

Fisher, D.J., Holloway, P.J., Richmond, D.V., 1972. Fatty acid and hydrocarbon constituents of the surface and wall lipids of some fungal spores. Journal of General Microbiology 72, 71-78.

Griffin, D.H., 1994. Spore dormancy and germination. In: Griffin, D.H. (Ed.), Fungal physiology. Wiley, New York, pp. 375-398.

Halbsguth, W., Rudolph, H., 1959. Untersuchungen über die Wärmeaktivierung der Sporangiosporen von Phycomyces blakesleeanus. Archives of Mikrobiology 32, 296-308.

Hawker, L.E., Abbott, P.M., 1963. Fine structure of vegetative hyphae of Rhizopus. Journal of General Microbiology 30, 401-408.

Hobot, J.A., Gull, K., 1977. The influence of glucose availability on events during germination of Syncephalastrum racemosum sporangiospores. Journal of General Microbiology 98, 431-437.

Horikoshi, K., Iida, S., 1964. Isolation and composition of the spore coats of Aspergillus oryzae. Biochimica et Biophysica Acta 83, 197-203.

Medwid, R.D., Grant, D.W., 1984. Germination of Rhizopus oligosporus sporangiospores. Applied and Environmental Microbiology 48, 1067-1071.

Rusmin, S., Ko, S.D., 1974. Rice-grown Rhizopus oligosporus inoculum for tempeh fermentation. Applied Microbiology 28, $347-350$.

Sussman, A.S., Halvorson, H.O., 1966. Spores, their dormancy and germination. Harper and Row Publishers, New York. 150-192 and $270-315 \mathrm{pp}$.

Tanuwidjaja, L., Roestamsjah, L., 1985. Preparation and utilization of powder form inoculum for tempe fermentation. ASEAN Food Journal 1, 22-24.

Thanh, N.V., Nout, M.J.R., 2002. Biomass and yield, viability and dormancy of sporangiospores of Rhizopus oligosporus as a function of tempe starter preparation conditions. Food Microbiology 19, 91-96.

Thevelein, J.M., Van Assche, J.A., Carlier, A.R., Heremans, K., 1979. Heat activation of Phycomyces blakesleeanus spores: thermodynamics and effect of alcohols, furfural, and high pressure. Journal of Bacteriology 139, 478-485.

Thevelein, J.M., Van Laere, A.J., Beullens, M., Van Assche, J.A., Carlier, A.R., 1983. Glucose-induced trehalase activation and trehalose mobilization during early germination of Phycomyces 
blakesleeanus spores. Journal of General Microbiology 129, 719-726.

Tripp, M.L., Paznokas, J.L., 1981. Relationship between sporulation medium and germination ability of Mucor racemosus sporangiospores. Journal of General Microbiology 127, 35-43.

Tripp, M.L., Paznokas, J.L., 1982a. Glucose-initiated germination of Mucor racemosus sporangiospores. Journal of General Microbiology 128, 477-483.

Tripp, M.L., Paznokas, J.L., 1982b. Role of amino acids and endogenous protein in the germination of Mucor racemosus sporangiospores. Journal of General Microbiology 128, 485-495.

Tunçel, G., Nout, M.J.R., Rombouts, F.M., 1989. Effect of acidification on the microbiological composition and performance of tempe starter. Food Microbiology 6, 37-43.

Van Assche, J.A., Carlier, A.R., 1975. Some properties of trehalase from Phycomyces blakesleeanus. Biochimica et Biophisica Acta 391, 154-161.

Van Assche, J.A., Carlier, A.R., Dekeersmaeker, H.I., 1972. Treha- lase activity in dormant and activated spores of Phycomyces blakesleeanus. Planta (Berl.) 103, 327-333.

Van Assche, J.A., Carlier, A.R., Van Tieghem, L.C., 1977. The effect of gramma radiation on breaking of dormancy in Phycomyces spores. Archives of Microbiology 113, 95-97.

Van Assche, J.A., Van Laere, A.J., Carlier, A.R., 1978. Trehalose metabolism in dormant and activated spores of Phycomyces blakesleeanus. Burgeff. Planta 139, 171-176.

Van Laere, A.J., Van Assche, J.A., Carlier, A.R., 1980. Metabolism and chemical activation of Phycomyces blakesleeanus sporangiospores. Experimental Mycology 4, 260-268.

Van Schaftingen, E., Van Laere, A.J., 1985. Glycerol formation after the breaking of dormancy of Phycomyces blakesleeanus spores. European Journal of Biochemistry 148, 399-404.

Wang, H.L., Swain, E.W., Hesseltine, C.W., 1975. Mass production of Rhizopus oligosporus spores and their application in tempeh fermentation. Journal of Food Science 40, 168-170. 